\title{
The Discovery of Gharabaa Byzantine Caravanserai, Near Site of Jesus Baptism-Jordan River
}

\author{
Mohammed Waheeb ${ }^{1}$, Abdull Aziz Mahmoud ${ }^{2}$ \\ ${ }^{1}$ Queen Rania College for Tourism \& Cultural Heritage, Hashemite University, Zarqa, Jordan \\ ${ }^{2}$ Department of History, Albayt University, Mafraq, Jordan
}

Email address:

mwaheeb@hu.edu.jo (M. Waheeb)

\section{To cite this article:}

Mohammed Waheeb, AbdullAziz Mahmoud. The Discovery of Gharaba a Byzantine Caravanserai, Near Site ofJesus Baptism-Jordan River. International Journal of Archaeology. Vol. 5, No. 3, 2018, pp. 19-25. doi: 10.11648/j.ija.20170503.11

Received: January 9, 2018; Accepted: January 19, 2018; Published: February 9, 2018

\begin{abstract}
Field archaeological survey in Jordan Valley on the eastern bank of Jordan River recovered architectural Byzantine remains of Gharabah caravansaries, close to site of Jesus Baptism along the historical pilgrim's route from Jerusalem to Mount Nebo. The main objective of this article is to shed light on the importance of the recovered architectural remains\& to link the site with other newly discovered stations along the pilgrims route from Bethany Beyond the Jordan to major Byzantine sitessuch assite of Jesus baptism. By systematic excavations, data analysis and comparative studies the work concluded in revealing two large water pools connected to each other by a long canal, and a major structure consists of a number of rooms and otherassociated facilities The discovery of Gharabah caravansaries considered as a progress step toward identification of lost pilgrims stations during the Byzantine Period from $4^{\text {th }}-6^{\text {th }}$ AD.
\end{abstract}

Keywords: Archaeology, Byzantine, Pilgrim Station, Cultural, History, Anthropology, Tourism

\section{Introduction}

There is a deeply- rooted desire in human nature to know exactly of the significance of historical events such as the real siteson pilgrims route near Jordan River. Modern archaeologists had some difficulties in identifying the sites where John the Baptist and Jesus Christ lived and taught. Indeed, they were sometimes embarrassed to find one or more sites for the same event. Consequently, and in order to get out of this dilemma, archaeological surveys and excavations were the only way to provide confident and explicit answers to such desires.

At the dawn of Christianity and shortly after Christ's birth in Bethlehem, John the Baptist, who was a priest at that time, started preparing for the arrival of Christ whilst roaming villages and cities on the eastern bank in Perea. [Kopp: 1963]

Holy text refers to different locations related to John and Jesus which was transformed later during the Byzantine Period to be pilgrims stations [Matthew 3:4]

Excavations supported the assumption that John the Baptist dwelt in Bethany Beyond the Jordan, which is located east of the Jordan River in the village of el-Kafrain. Near this village there is a valley called Wadi el- Kharrar that is less than $2 \mathrm{~km}$ away from the Jordan River [Waheeb: 1997; 1998; 1999].

Important events regarding the early beginnings of Christianity took place in this valley. Most people believed that Jesus was baptized in the traditional baptizing site in Jordan River. However, the early Christian pilgrims, travelers, and historians who followed the scientific method in their studies\& descriptions, presented us with detailed explanations regarding the religious sites related to the baptism of Jesus and other related holy sites. These explanations coincide with the results of the archaeological excavations and with the biblical verses as well [Wilkinson, 1977].

\section{The Discovery of Bethany Beyond the Jordan}

Bethany Beyond the Jordan located on the eastern side of Jordan River at a distance of $40 \mathrm{~km}$ from Amman capital of modern Jordan \& less than $8 \mathrm{~km}$ north of the Dead Sea. Systematic excavations reveled the presence of churches, 
hermit caves, water system installations, and other facilities designed for pilgrimage dated from the $3 \mathrm{ed}-18$ th $\mathrm{AD}$.

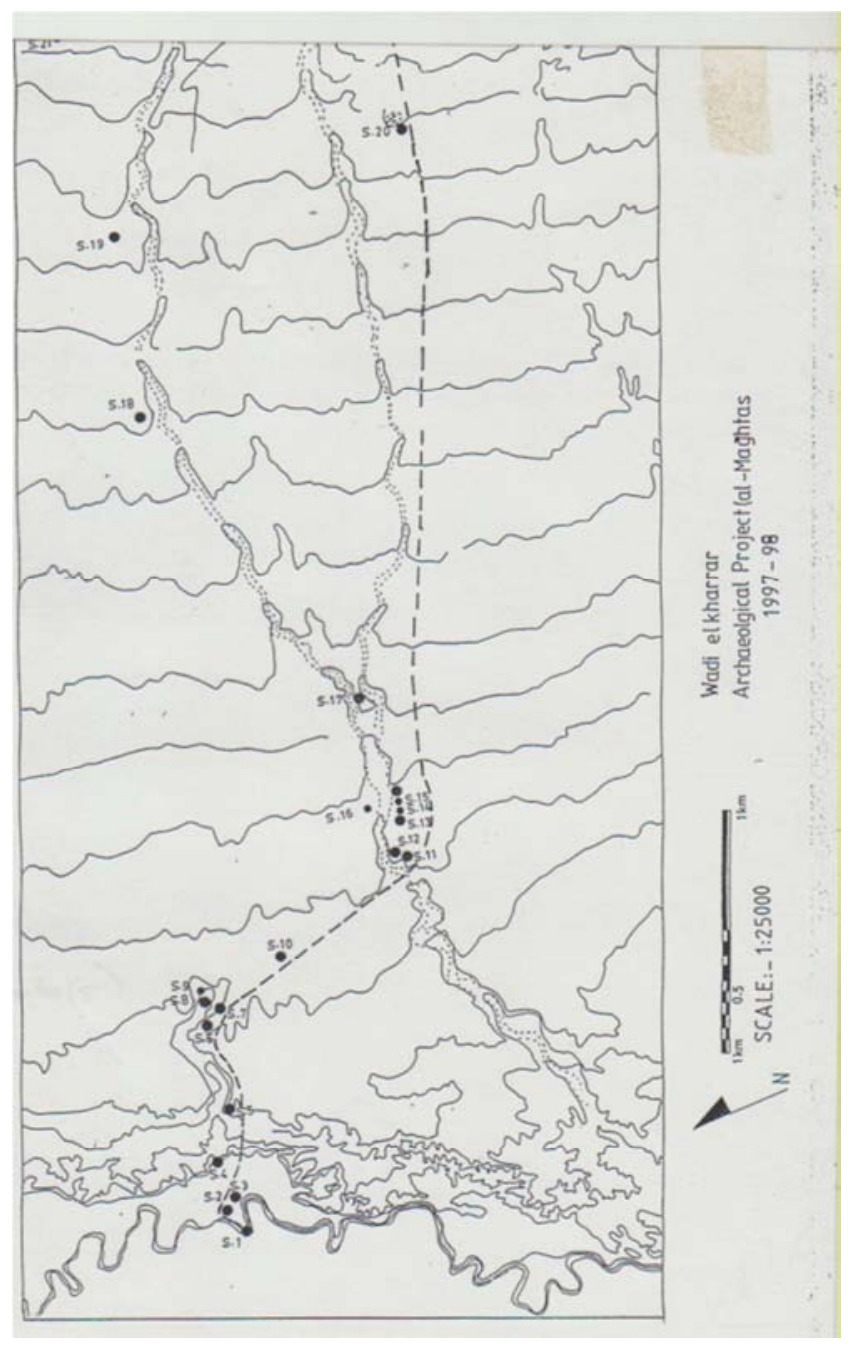

Figure 1. A map showing the location of pilgrims stations on the eastern bank of Jordan River [Waheeb 2009].

Considering the importance of such site was a priority, to protect it from further destruction, by the effect of erosion especially that the area is made of lissan marl formation. The team worked hard to face the danger of minefield and endure the harsh climate of the Jordan valley in its quest to answer questions such as: Where did baptizing of the Christ and John the Baptist took place? Where were the pilgrim'sstations located along the pilgrim road? And whether this road was the same road taken by the Christ when he arrived at the area and left it. However, perhaps the question, which answers all the enigmatic questions, should be as follows: Where is the spot from which Christianity was spread into the world? To answer these questions, the fieldwork was necessary, and whatever results reached should be accurately analyzed in an objective way [Morton, 1934]. [Figure 2].

\section{Pilgrims \& Travelers Description}

As it is well known, the early pilgrims, who came from all around the world to visitJerusalem and Bethlehem, headed afterwards to Jericho to cross the Jordan River ${ }^{1}$ to the east bank, where John the Baptist once preached the crowds. [Waheeb 1997;1998]

The discovery of the real site of baptism gave rise to many questions, because the general idea was that Jesus was baptized in the Jordan River, whereas archeology findings indicate that it was to the east of the Jordan River. Thus, it is only fair to consider the site supported by scientific evidence and proof as the true site of baptism i.e. the site east of the Jordan River. The site facing Jericho was merely chosen as a traditional site due to its closeness to Jerusalem ${ }^{2}$.

Many witnessed the arrival of the Christ at Bethany. That is clear in the verse that says that John's disciples came to him inquiring [And they came unto John, and said Rabb, he that was with thee beyond Jordan][John 3:26]. This proves beyond the shadow of doubt that the baptism site is to the east of the Jordan River.

Theconvey of early pilgrims came to Wadi el-Kharrar, which is in the center of Bethany, where the prophet Elijah was expecting the arrival of Jesus. On the other hand, pilgrims and believers also arrived at the place where the Lord was baptized to visit it, get the blessings, and sometimes to even dwell close to it.

Some of them described the place elaborately. For example Bordeaux, who visited the area in 333 A.D. said that the baptism site is close to Wadi el-Kharrar, where modern excavations are conducted in the meantime [PPTS, 1887]. Where the traveler [Theodosius] who visited the site in 754 AD emphasized on the fact that the baptism site lies to the east of the Jordan River, and that the Byzantine emperor [Ansatasius] built John the Baptist is church on the spot where the Lord was baptized. Further he remarked that the church was built on arches and vaults to protect it from the flood ofthe Jordan River in winter [PPTS, 1893].

Arculf St [PPTS, 1895a]. Willibald [PPTS, 1895b] and the Russian traveler Danial Abbot emphasized that Christ was baptized in the east bank, where a church was built on the edge of the River to commemorate the event.

Thus, it is clear that the baptism took place on the east bank, and that John's church represents a crossing point to the sacred place where the first believers were John was first

1 [Repent ye: for the kingdom of heaven is at hand.”, before he baptized them in the Jordan River. In that exact spot, where the murmurs of the Kharrar spring could be heard, Jesus Christ asked John the Baptist to baptize him, and John answered: "I have needed to be baptized of thee, and comest thou to me?" But Jesus answering said unto him, "suffer it now: for thus it become thus to fulfill all righteousness. Then he suffered him.] [Matthew 3:15]

2 This fact was strongly supported by biblical verses, which mention that baptism took place in Jordan, [Then cometh Jesus from Galilee to the Jordan unto John, to be baptized of him.] [Matthew 13:3]; also, we can see another verse:

And it came to pass in those days that Jesus came from Nazareth of Galilee, and was baptized of John in Jordan". [Mark 1:9] where the last verse in Luke shows: "Now it came to pass when all the people were baptized, that Jesus also having been baptized, and praying. The heaven was opened" [Luke 3:12] Furthermore, we can track another verse says:

[These things were done in Bethanybeyond Jordan, where John was baptizing.] [John 1:28], "And he went away beyond Jordan into the place where John was at the first baptizing; and there he abode] [John 10:40]. Consequently, these verses verify that Jesus headed to this location. 
baptizing, and is where Jesus was baptized as well.

The results of archeological survey and excavations were consistent with the travelers' description [Wilkinson, 1981]. The foundations of the church were soon found, with its arches and vaults, and these protect it from the flood of the river, which is about half kilometer away.

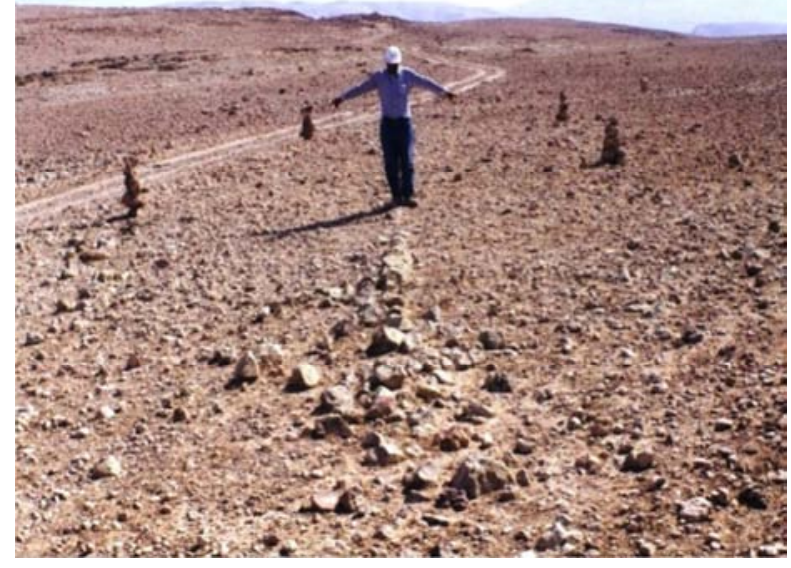

Figure 2. Remains of stone cobbles on pilgrim's road (Waheeb, 2006).

Bethany is the sole place where churches were built continuously regardless of the fact that the floods may destroy them. In addition, the monks who dwelt the area carved their places in rock; these small caves became places for prayer, where the monks relived the lives of the first believers. We should not disregard what the travelers said about the existence of Elijah's and John's caves, in the spot where many saints and prophets have passed. [Waheeb, 2015]

The pilgrims then gradually ascend to the northern bank of the Holy Valley [Wadi el- Kharrar] alongside the murmuring of the spring that gave it its name, and under the shades of palm trees, tamarisk, and thick vegetation that cover the valley. They can rest next to a large pool designed to collect water from Wadi el- Kharrar through a channel.

It is clear that the pilgrims rested near this pool since a small building, built on a plan facing Wadi el-Kharrar and the Jordan River, it was discovered. This building represents a church was built for the sake of the pilgrims.

The discovery of the pool is quite impressive, since it is the only pool that is feed by John's spring. The pool was built to facilitate mass baptizing once the pilgrims enter the Holy Valley, and before they head to the church for prayer. Soon afterward، they continued their pilgrimage to John's church, and on their way, they encountered a small structure built by a monk for the purpose of prayer and abstinence in this holy spot. The convoy reaches the church of Elijah, where one stands and contemplates the remains of buildings that are spread all over the area. The verse "where John was first baptizing"; echoes into one's mind, for the active spring still beats down the hill and the resonance of its murmurs is still heard in the wilderness. [PPT, 1886]

This valley is of peerless beauty between the Jordan valley [el-Ghor], where it suddenly descends without reaching the eastern meadows, and runs westwards till it reaches the
Jordan River, in which the water breathers life into it.

The first building that the pilgrim sees is the small-sized church, which gives us an idea about the roof that was raised on vaults, the mosaic floor ornamented with cross shapes, and the courtyard that faced north and contains the largest water tank. The roof of the structure was shaped into half a cylinder, and the upper surface was leveled and paved with white mosaic [Waheeb, 2007; 2008; 2015]

To the east of this church, the pilgrim can see a small building that must have been built for religious purposes. Remains of the water system were found next to the northern edge of this building. Clay pipes were used to draw sweet water from the Gharabeh valley, which is 2 kilometers away [figure, 3 ].

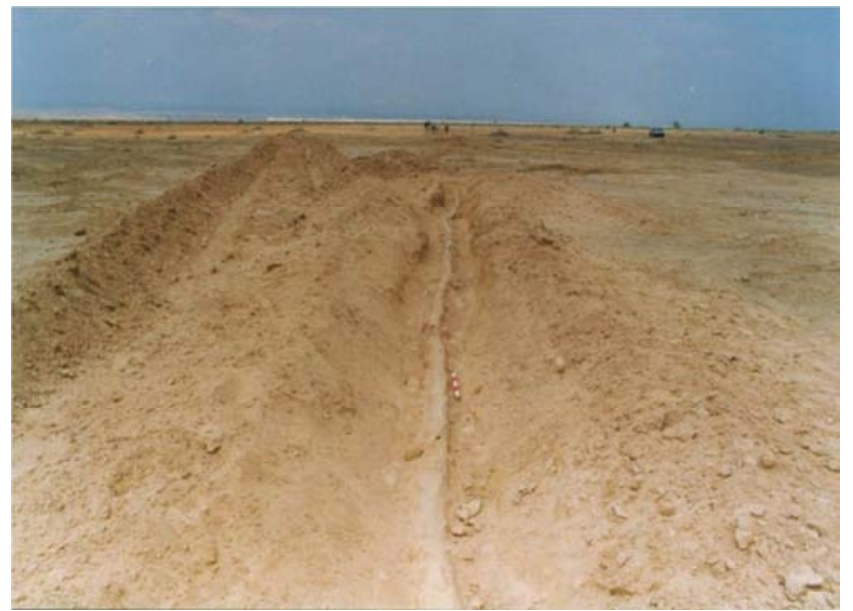

Figure 3. A ceramic waterpipes links Wadi Gharabh station with Baptism site [Waheeb, 2000 ].

Precipitation tanks used to clarify the waters were found as well, along with a large tank seven meters deep.

Channels were spread into the Kharrar to feed the pools and tanks there. In addition to that, one can view that a protective wall to preserve the structures that are built on its slopes surrounds the Tell. A medium-sized church was discovered on the northern side of the wall, another on the western side and the remains of a mosaic floor were discovered on the northwestern side. All this may show the immense effort given to build these structures. [Waheeb, 1998a,b].

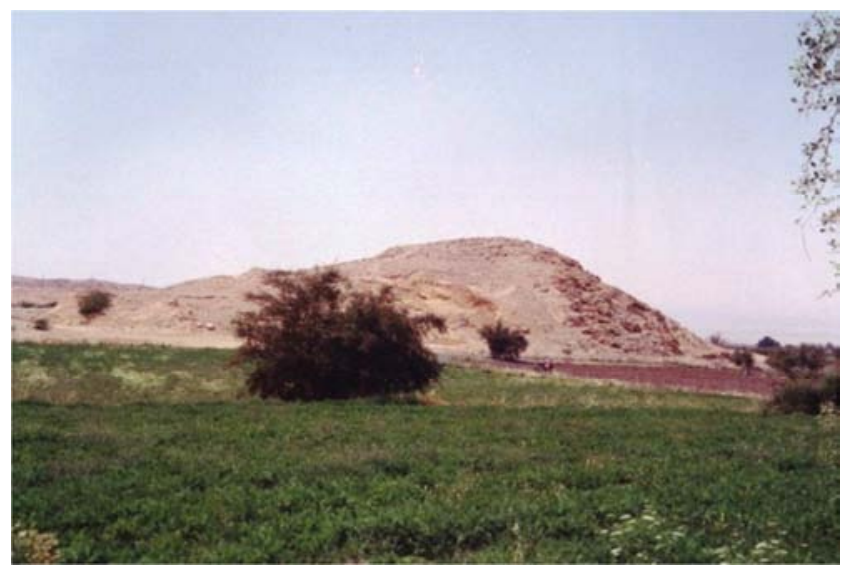

Figure 4. Tell Iktanu near the pilgrims route [Waheeb, 2015]. 
Archeological sites located near the road among of them Tell Husban and Tell Iktanu [Esbus Jericho Road] [Figure 4]. One may wonder why were these buildings constructed on this small low hill on the edge of a valley, subjected to the harsh elements of nature? The only logical answer is that emperors and monks competed to build religious buildings on the site due to its holiness. By these acts, they only aimed to please God. For example, the name of the priest [Roterrious], who was the head of Wadi el-Kharrar's monastery, was found among the inscriptions found on the
Tell. [Piccirillo, 1987; Wilkinson, 1981].

\section{Wadi Gharabah Caravanserais}

The pilgrims who are leaving Bethany continue their pilgrimage along the side of the ceramic channels, which were constructed to supply the pilgrims with water. A distance of one kilometers to the southeast direction will bring the pilgrims to the Gharabeh Valley [see figure 5], were huge pools and rest station were constructed.

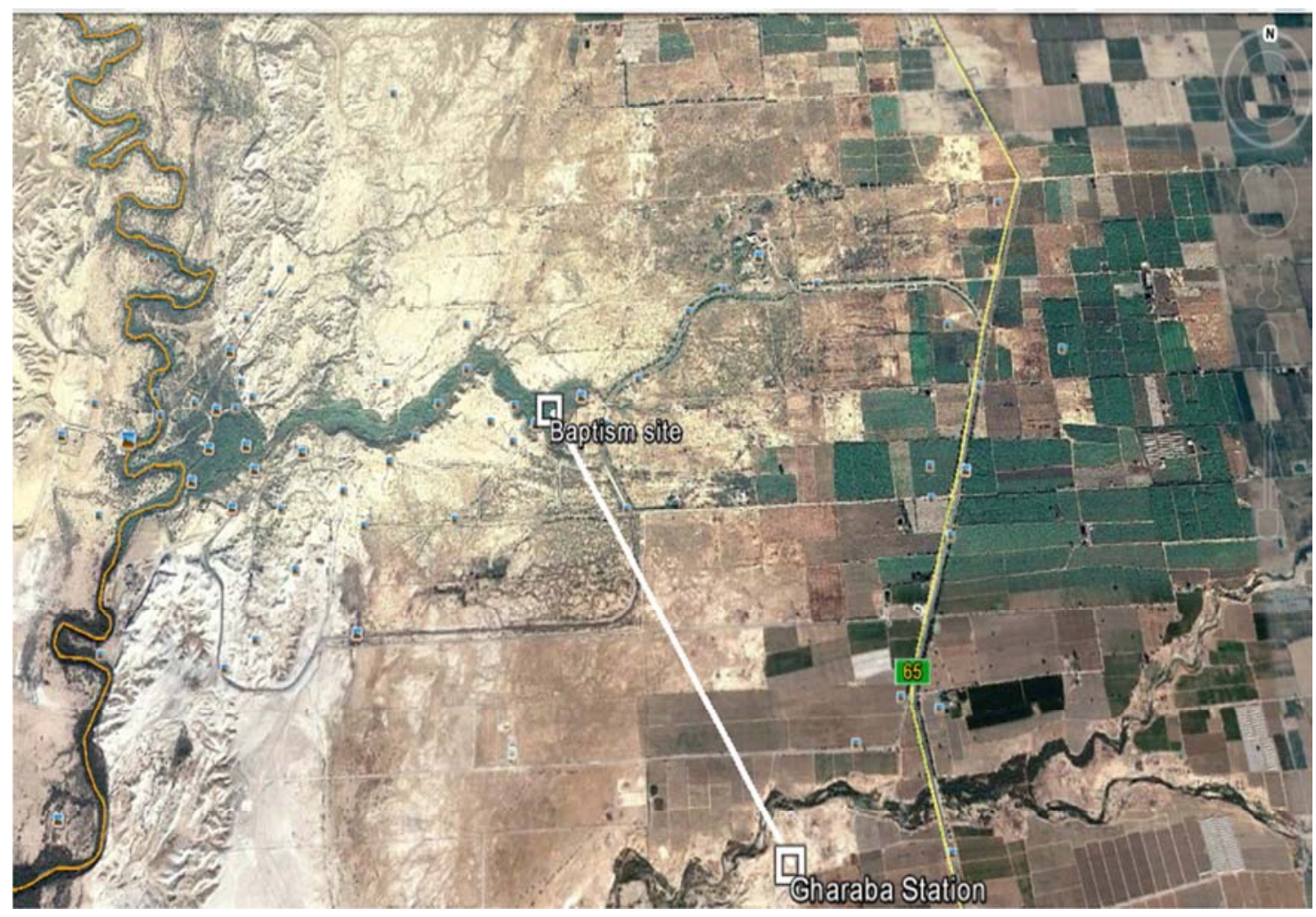

Figure 5. Aerial photo showing both sites Bethany and Gharabah Station [Google map, 2017].

\section{Site Description:}

Wadi Gharaba structure, is a major Byzantine [Early - Late Byzantine] fort and caravanserai. The site consist of two large pools, a channel as well as the fort in the middle, there are extensive agricultural fields associated with the structures. The site is located at the southern end of Wadi Gharaba. Fieldwork survey and excavations gives the measurements of the two reservoirs connected by a channel and pilgrim station were built in the middle between the two pools ${ }^{3}$.

\subsection{The Eastern Pool: [Figure, 6]}

The Eastern reservoirs measurements [ $30 \times 34.5 \mathrm{~m}] ; 0.5 \mathrm{~m}$ of the high of the pool walls is still standing; the walls built by $0.5 \mathrm{~m}$ width of small size pebble stones mixed with lime mortar as a foundation, the upper courses built and consist of middle stone size; the inner sides of the walls covered by white plaster. On the other hand, the eastern wall of the pool

3 The team consisted of five archaeologists, engineer, draftsman and logistic support staff headed by the author during winter/February of 2002. was destroyed as a result of ignorance during the last decades.

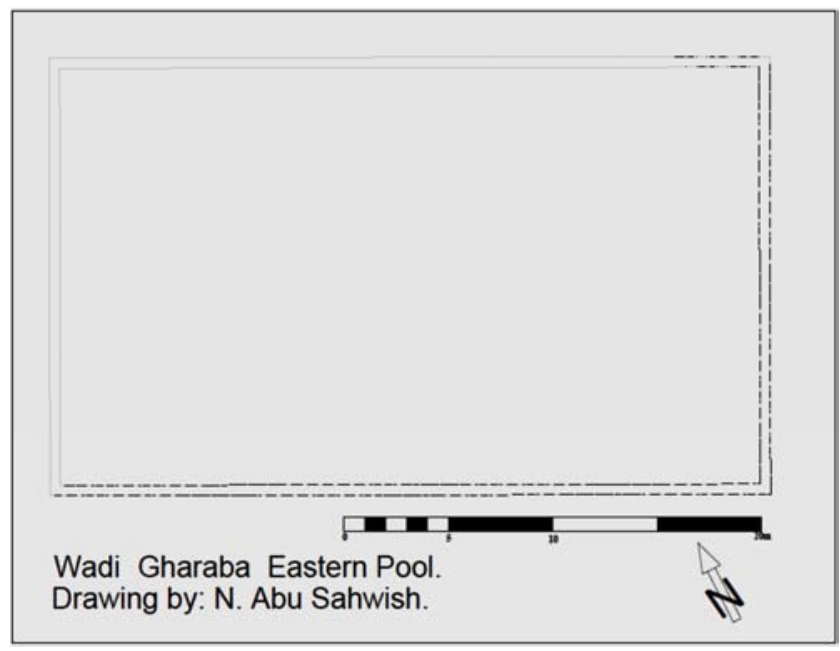

Figure 6. Top plan of the eastern pool [Abu Shawish 2016]. 


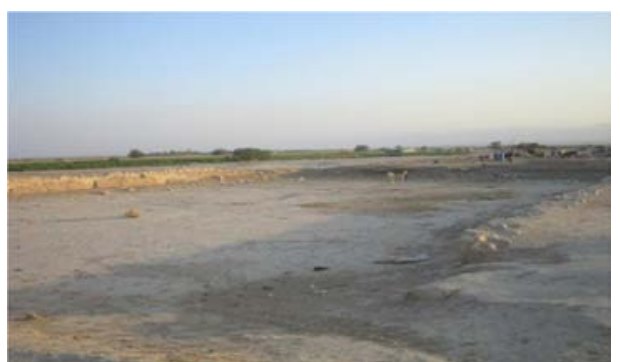

Figure 7. Photo of the eastern pool with its remaining walls [Waheeb, 2002].

\subsection{The Western Pool:[Figure, 8 \& 9]}

The western reservoir measures [24 x $24 \mathrm{~m}$ ] as part of the walls of the structure was ruined in antiquity while most of the upper courses were demolished. The walls still stands for considerable height, the east wall ca. $0.50 \mathrm{~m}$ high; while the north wall ca. $1.00 \mathrm{~m}$ high; and like the inner walls was coated with the plaster layer in order to prevent any seepage. Remains of plaster can still be seen both on the interior and exterior walls the entire structure is built of limestone blocks. The steps, which lead down into the reservoirs, are not clear.

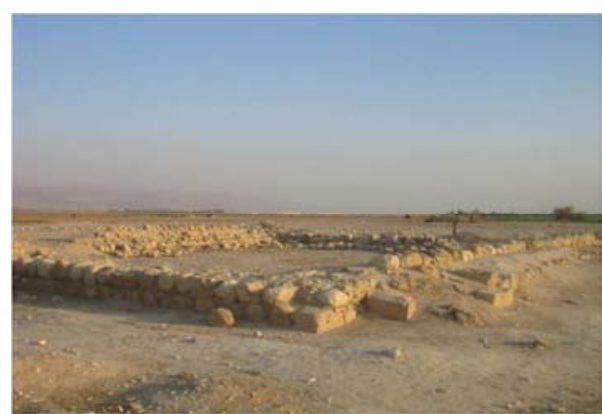

Figure 8. Photo of the western pool [Waheeb, 2015].

\subsection{The Channel}

Remains of the channel which brought and transport the water from Eastern to the Western pool still can be seen on the ground, built of two rows of medium to large limestone blocks, only the foundations were found in situ while the upper fragments of the channel were lost during the last years, the total length of the channel is around $307 \mathrm{~m}$ connecting the two pools and passing near the southern side of the caravanserai.

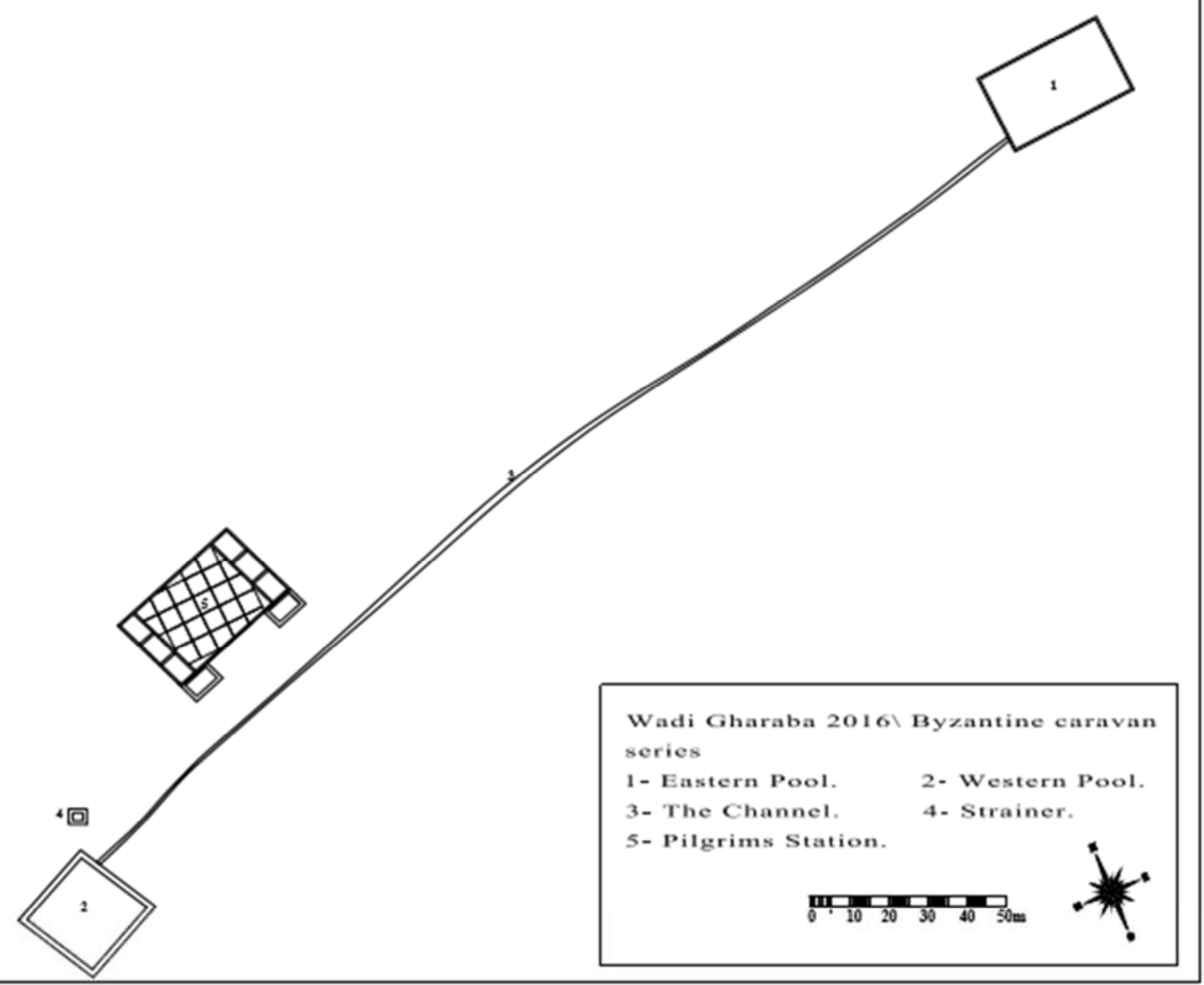

Figure9. Plan of the Channel of the water during field assessment [Waheeb, 2002]. 


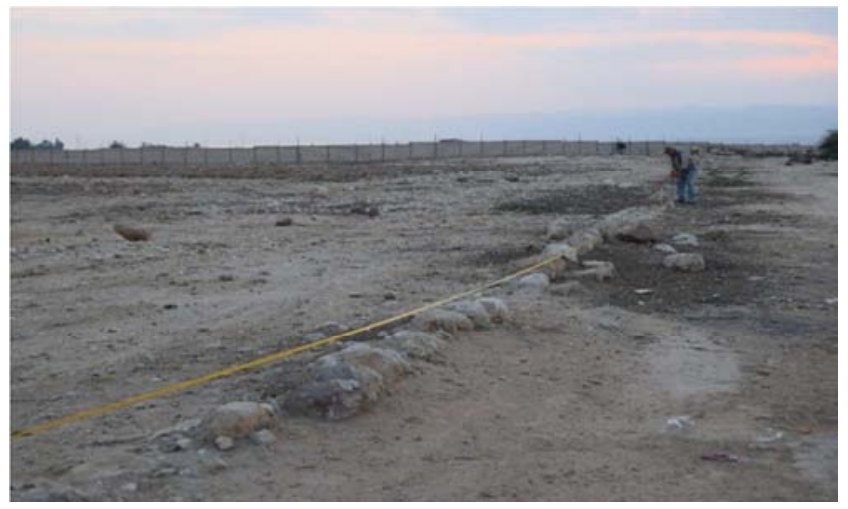

Figure 10. Photo of the channel during field assessment [Waheeb 2002].

\subsection{The Pilgrim Station}

The caravan/station is [rectangular building] located ca. $50 \mathrm{~m}$ to the northeast of the second reservoir. A grid established and more than 20 squares were opened, excavations revealed the presence of caravansaries consist of rooms built around the central courtyard, three rooms were recovered on eastern side while other three rooms found on the western side.

It measures ca. $22.60 \mathrm{~m} \mathrm{NSx} 37.60 \mathrm{mEW}$ the general shape isrectangular and has two, apparently square corner towers. The towers could be still seen projecting from the southern wall of the station, despite the ruined condition of the structure, on the 2000 aerial photos. The walls measure ca1. $20 \mathrm{~m}$ thick. The fort has been recently suffered by damage caused by agricultural field activities.

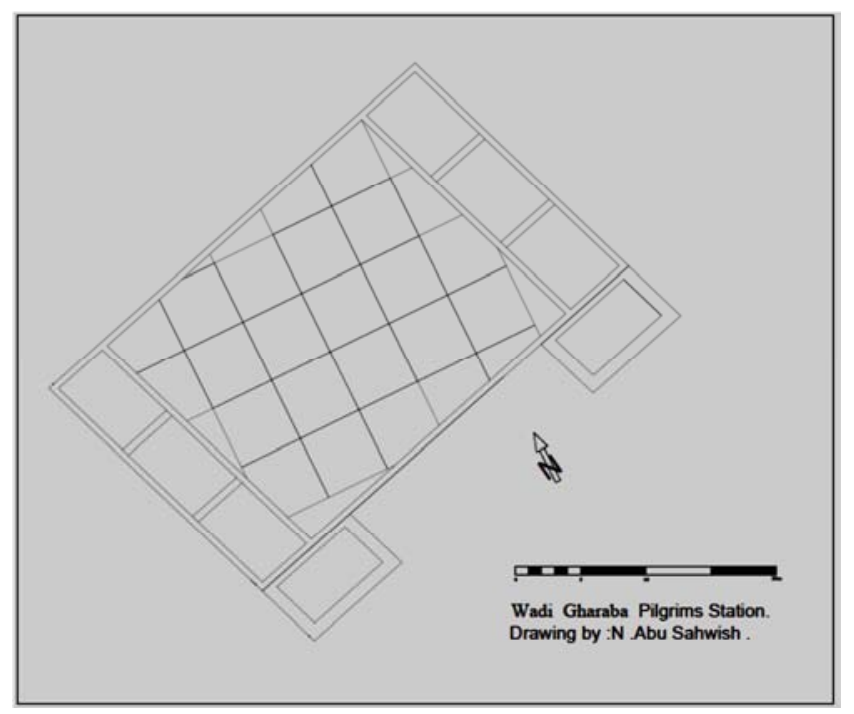

Figure 11. Topplan ofthepilgrims station and associated structures [Abu Shawish, 2012].

The internal partitions are still visible; a looted pits was noted in the middle of the structure. Many of the terracing walls in the agricultural fields to the west and north are clearly visible in some places these walls have been destroyed by human and/ or natural causes. The team of the excavations collected Classical pottery sherds, few Early Roman sherds were found scattered, while most of the stratified materials such as pottery are Byzantinedated to late period of occupation at the site. However, few Islamic pottery Umayyad were foundwhich refers to continuity in using the site after the Muslims conquest of the area in the Seventh Century AD, excavation clarify the date of the building and use of the various segments of the site.

\section{Conclusion}

During Byzantine periods several techniques of caravanserai planning were adopted, including baths and fountains in addition to public and private facilities. Gharabanear Bethany beyond the Jordan was provided with water from the nearby Wadi for cultic utilization, and also connected with Bethanythrough artificially made ceramic pipes still in situ. The ceramic pipes and the water channels that reached Bethany supplied several pilgrims stations used by pilgrims inside Bethany, While identical channels, watchtowers, caves and natural poundswere found during our field surveyon both alignment ofthepilgrims road between Jerusalem, Jericho, Bethany beyond the Jordan, Wadi Gharaba, Wadi Hesban and Mt. Nebo.

The natural pounds developedtopools and cisterns, associated with the settlement of John the Baptist, recognized and adopted from the 4th-7th century A. D by the Byzantines, which is now well identified close to Gharabacaravanserai, represent one of the important discoveries east of Jordan River.

The archaeological evidence uncovered at Gharaba is sufficient to allow a reconstruction of the appearance of the complex. The reconstruction emphasizes its character of as a caravanserai. The buildings, water system, and pools represent a unique caravanserai. situated in the wilderness on the pilgrims route.

The survey and excavation has documented the ancient pilgrimage route that linked Jerusalem, via the Jordan River and Bethany east of Jordan, through Gharabato Mt. Nebo. Several Byzantine churches and other structures have been identified between the river and Mt Nebo and weresubjected to limited excavation and assessment. Some of them commemorate Jesus' baptism while other structures were monasteries for ascetic monks. This discovery as well as othe new discoveries such as Jesus Cave in Iraq Al-Ameer \& Aenon Near to Saleem on the pilgrims route will enable the schoolars and researchers to rewritethe history of byzantine civillization and christiantyon the eastern bank of Jordan River.

\section{References}

[1] Morton, M 1934In the steps of Master, london.

[2] Piccirillo, M. 1987 The Jerusalem-Esbus Road and its sanctuaries in Transjordan pp. 165-172, Studies in the History and Archaeology of Jordan 31,1. ed. A. Hadidi. Amman: Department of Antiquities. 11-1919. 
[3] PPTS 1886 The Building of Justinian by Porocopius 560 AD.

[4] 1887 The Bordeaux Pilgrim 333 AD., Translated by J. H. Bernard, pp. 1-19, Hanover Square, London. See also Theodosius, 1893, on the Topography of the Holy Land 530 AD, Translated by J. H. Bernard, pp. 1-19, Hanover Square, London.

[5] 1895a The Pilrimage of Arculfus in the Holy Land [670AD] p. 43 London 1895 Palestine Pilgrims' Text Society Vol. III.

[6] 1895b The Pilgrimage of the Russian Abbot Daniel in the Holy Land [1106-1107AD] p. 29 London 1895 Palestine Pilgrims' Text Society Vol. IV.

[7] Kopp, C, 1963 The holy places of the Gospels Germany.

[8] Waheeb. M. 1997 Report on The Excavations At Wadi AlKufrayn Souhern Ghors [Al- Aghwar], Annual of The Department of Antiquities of Jordan, 41, P.: 463-468.

[9] 1998aNew Discover iews near the Baptism site [Jordan River][Al Maghtas Project]Occident and Orient Vol. 3, No. 1, p.19-20.

[10] 1998b Wadi el-Kharrar [al-Maghtas] AJA Vol. 102, No. 3, p. 106.
[11] 1999 Wadi el-Kharrar Archaeological Project. The Monastery ADAJ Vol. XLIII, p. 549-557.

[12] 2000Bethany Beyond the Jordan (Booklet)published by JTB, Amman.

[13] 2007 Bethany Beyound The Jordan Site of Jesus Baptism Discovery and Assessment. Online Anistoriton-No. 788.: 1-12.

[14] 2008 The Discovery of Bethany Beyound the Jordan Wadi AlKharrar - Dirasat, Jordan University, vol. 35. No. 1.

[15] 2006 The archaeological discoveries on the eastern side of Dead Sea, Al-Mjallah Al-IlmiyehL Kulliyat Al-Adaab, 38, pp 1-35.[Arabic].

[16] 2015 The Discovery of Tall Mar Elyas, in The Baptism Site, Jordan, $1^{\text {st }}$ edition, Amman.

[17] Wilkinson. J., 1977 Jerusalem Pilgrims before the Crusades. Ariel Publishing House, Jerusalem.

[18] 1981 Egerias Travel to the Holy Land, Jerusalem. 